The weakness in this anthology, as in the underlying project, is that, in its attempt to provide a comparative analysis, it is unclear why Sri Lanka and the former Yugoslavia were chosen as the regions of study. The (somewhat cumbersome) introduction attempts to justify the comparative project, despite the many differences, but never explains why regions like Palestine and Rwanda were not included. The project was hosted by York University in Toronto, and neither the introduction nor the essays discuss the geopolitical role and function of this location as facilitator. Finally, reading the anthology is both utterly painful and inspiring. Not only are the effects of war so devastating, but the general inability of feminists to penetrate political processes in significant ways is worrisome. At the same time the hope, perseverance, and initiatives discussed in the book are inspiring, and should pave the way to thinking and working towards deeper and necessary social changes.

DORIT NAAMAN

Dorit Naaman teaches film studies and specializes in Middle Eastern cinema at Queen's University in Canada. She is currently involved in a large research project on the representation of Palestinian and Israeli women fighters.

\title{
Problems of Protection: The UNHCR, Refugees and Human Rights
}

Niklaus Steiner, Mark Gibney and Gil Loescher, Editors

New York and London: Routledge, 2003

$\mathrm{F}$ iftieth anniversaries are traditionally celebrated with gifts of gold. However, in the case of the UNHCR and the 1951 Convention, the gift of choice appears to be paper: pages and pages of paper filled with opinions on the past, present and future of refugee protection. One of the most recent gifts of this sort, Problems of Protection: The UNHCR, Refugees and Human Rights, edited by Niklaus Steiner, Mark Gibney, and Gil Loescher, attempts to offer a critical assessment of the past half-century of refugee protection under UNHCR.

The Problems of Protection is an outgrowth of a conference held at the University of North Carolina in the spring of 2000. The thirteen essays that make up the book are grouped, by subject matter, into five sections: definitional issues, ethical issues, legal and institutional issues, policy issues, and the post-September 11 context of refugee protection. The essays in the last section were obviously commissioned subsequent to the conference and show less evidence of being part of the "ongoing dialogue" that informed the other essays.

Arthur Helton and Gil Loescher provide the opening two essays, both related to the definitional issue of the meaning of "refugee protection" - and the related topic of UNHCR's diminishing interest in the subject. Loescher traces the erosion of the UNHCR's protective mandate to the politicization that was entailed by the expansion of its mandate since the dying years of the Cold War. While Helton does not dispute this premise, he nonetheless professes hope that the expanded mandate of the UNHCR can enhance its ability to "proactively" assist those in need of protection. Ultimately, both authors argue that only greater resources and political attention, by both the UNHCR and its funders, can refocus the UNHCR on its mandate to protect refugees.

In a sense, the subsequent "dialogue" of the book can be framed in terms of Helton's and Loescher's subtly diverging views on the central actor in refugee protection: the UNHCR or a statist international community. Loescher acknowledges the UNHCR as both a mechanism through which states act and as "a principal actor" in its own right. Notwithstanding this dualism, he addresses his concerns to the UNHCR qua principal actor:

UNHCR is not a static organization but has constantly changed and evolved over the past fifty years. Dramatic and bold steps should now be taken to revitalize UNHCR's primary role as the protector of refugees and the guardian of asylum worldwide. ${ }^{1}$

While Helton shares Loescher's concern about UNHCR's declining attention to the protection of refugees, his prescription favours UNHCR's alternate persona: UNHCR qua a mechanism through which states act (or, in this case, fail to act). This approach is perhaps based in Helton's understanding of the statist nature of the 1951 Convention and his oft-quoted premise that "when we speak of 'protection' we mean legal protection." 2 In keeping with his approach, Helton's examples of "proactive" refugee policies (particularly his proposal for a meeting of state "stakeholders" to resolve the West African refugee crisis) all involve increased action by the "international community" (read: state actors and subcontracted NGOs). ${ }^{3}$

The agent-versus-actor dichotomy expressed by, respectively, Helton and Loescher repeats itself throughout the 
collection of essays, with about half on each side of the divide. Viewed from the point of view of this dichotomy, Brian Gorlick's essay on refugee protection and human rights is perhaps the most interesting. Gorlick attempts to reconcile the burgeoning literature and jurisprudence on human rights with both international refugee law and the actions of the UNHCR. Although he spends much time describing various human rights developments and mechanisms, his essay is most interesting when it (perhaps too briefly) approaches the issue of the increasing overlap of human rights and refugee law from the point of view of the UNHCR as an agent. His resulting discussion of whether and how the organization has incorporated human rights into its policies and procedures is a topic that will hopefully be picked up in subsequent writing.

In a different way, Elizabeth Ferris's analysis of the role of NGOs in the protection of refugees also deals with the agent-versus-actor dichotomy insofar as it is embodied in the civil society "movement" that has engulfed NGOs, including those involved in refugee protection. Ferris's essays provide a good overview of the parasitic (in the original, if not always colloquial, use of the term) relationship between NGOs and the UNHCR. Ultimately, she suggests that whereas NGOs were initially seen as agents of the UNHCR, the expansion of both UNHCR and the NGOs has led to a much more active role for NGOs in the protection of refugees. In a foreboding passage, she also questions the increasing obstacles that face NGOs and others protecting refugees:

In the past few years, the murders of UNHCR, ICRC and WFP staff in East Timor, Sierra Leone, Chechnya and Burundi has led to intensive soul-searching debates over staff security and the limits of acceptable risk. Many NGO staff have also been victims of the violence inherent in trying to provide relief in situations of armed conflict. It is increasingly difficult to protect refugees and displaced people in all regions of the world. ${ }^{4}$

Of course, it would be a gross simplification to characterize the essays as merely commentaries on the legal personality of the UNHCR. The usual mix of optimism and pessimism and arguments for expansion and contraction can be seen within and between the essays. It would also be a mistake to portray the book solely as a philosophical debate. The essays broach a number of practical issues that have perpetually plagued refugee protection, including the flexibility of the definition of "refugee" (Bonny Ibhawoh on cultural relativism and FGM and Emily Copeland on the growing recognition of gender-based persecution); the appropriateness of repatriation (Beth Whitaker on the Rwan- dan repatriation fiasco of December 1996); and the public debate about refugees in the developed world (Niklaus Steiner on the debate in Europe).

Although all of the essays are of a high quality, they often belie their origins as conference papers. In this sense, the book is directed at those readers "in the field" of refugee protection as understood in a concrete, rather than abstract, sense. At times, sources and arguments are not as formally referenced or supported as would be required in an academic publication (perhaps most obviously in Ibhawoh's essay on cultural relativism, admittedly a subject that it is impossible to do scholarly justice to in the span of fourteen pages). Even ten months after publication, the essays seem at times dated - an observation perhaps highlighted best by the below-noted events subsequent to its publication. Certainly, the post-September 11 "securitization" discussion has filled in and elaborated upon the sketch presented in van Selm's essay. Furthermore, the essays make at best cursory mention of the High Commissioner's "Agenda for Protection." While the critics of "Convention Plus" may retort that there is not much to mention, it would have been interesting to integrate an analysis of the UNHCR's own response to its fiftieth anniversary into the book.

In closing, less than four months after the publication of the book, two of the authors learned first-hand of Ferris's "increasing difficulty" of refugee protection. In August 2003, Arthur Helton was killed and Gil Loescher was seriously wounded in the bombing of the UN Headquarters in Baghdad. No one can question the commitment of either author to the protection of refugees. As we pay tribute to their dedication, the essays contained in The Problem of Protection lead us inevitably to ponder Helton's question: "How committed is the international community to refugees and displaced persons?"5

\section{Notes}

1. Niklaus Steiner, Mark Gibney and Gil Loescher, eds. Problems of Protection: The UNHCR, Refugees and Human Rights (Routledge: New York and London, 2003) at 17.

2. Ibid. at 20 (emphasis in the original).

3. Ibid. at 31 to 33 .

4. Ibid. at 128.

5. Ibid. at 33 .

Martin Jones

Martin Jones is a former refugee lawyer and is presently a graduate student at Osgoode Hall Law School at York University. 